\title{
obituary
}

\section{J. Bronowski}

DR JACOB Bronowski died on August 21, 1974, aged 66. A mathematician, he won acclaim for his work in popularising science in books, on radio and in television broadcasts.

Bronowski was born in Poland and came to Britain in 1920 . He read mathematics at the University of Cambridge from 1927 to 1930 and continued research there until 1933. A senior lecturer at the University of Hull from 1934 to 1942 he left to head a number of statistical units dealing with the effects of bombing. In 1945 he wrote the classic report The effects of the Atomic Bombs at Hiroshima and Nagasaki.

He was engaged in applying mathematical analysis to the economics of industry until 1950 when he became Director of the Coal Research Establishment of the National Coal Board and was responsible for the development of a new process for making smokeless fuel. In 1964 he joined the
Salk Institute for Biological Studies in San Diego, becoming Director of the Council for Biology in Human Affairs in 1970.

Bronowski published many books including Science and Human Values, and The Western Intellectual Tradition. $\mathrm{He}$ was a popular broadcaster and his most recent television series was the award winning The Ascent of Man made for the $\mathrm{BBC}$.

\section{C. Craig}

Lyman C. Craig whose invention of the counter-current distribution process has been particularly useful for the isolation and study of synthetic antimalarials, antibiotics, hormones and proteins died on July 7, 1974.

Dr Craig began his structural studies on the alkaloids of ergot in 1933, when he came to The Rockefeller University as an assistant to Dr W. A. Jacob, and later isolated lysergic acid. During the Second World War he worked on the chemistry of antimalarial drugs for the Office of Scientific Research and Development.

\section{R. Cruickshank}

Professor Robert Cruickshank, CBE, died on August 16, 1974 aged 74. $\mathrm{He}$ was prominent in forging many links between academic and public health microbiology.

He graduated from the University of Aberdeen in 1922 and, in 1928, was appointed Lecturer in Bacteriology at the University of Glasgow and Bacteriologist to Glasgow Royal Infirmary. Eight years later he became one of the first group pathologists of the London County Council and, in 1945, was appointed Director of the Central Public Health Laboratory Service. He succeeded Alexander Fleming as Professor of Bacteriology at St Mary's Hospital in 1948 and became Director of the Wright Fleming Institute of Microbiology. From 1958 until his retirement in 1966 he was Professor of Bacteriology at the University of Edinburgh.

\section{Announcements}

\section{Appointment}

G. R. Serjeant has been appointed director of the Medical Research Council's Epidemiology Unit in Jamaica.

\section{International meetings}

September 23--27, 22nd Symposium of Vertebrate Palaeontology and Comparative Anatomy, Manchester (D. W. Yalden, Organiser, 22nd Symposium of Vertebrate Palaeontology and Comparative Anatomy, Department of Zoology, The University, Manchester M13 9PL, UK).

October 2-5, International Conference on Surgery, Traumatology, Angiology Anaesthesiology and Reanimation, Budapest (Office for Conference Organisation, (MOTESZ) H-1361 Budapest, POB 32, Hungary).

October 3-6, 6th International Symposium on Clinical Pharmacology and Annual Meeting of the International Society of Clinical Pharmacology, Regensburg (International Symposia on Clinical Pharmacology, General Office,
D-8400 Regensburg 1, PO Box 345, German Federal Republic).

October 7-12, International Exhibition and Symposium on Elements and Systems for the Preparation, Collection and Transmission of Data and other Peripheral Units of Computers: DATOS 74, Bratislava (House of Technology of the Slovak Scientific and Technological Society, Bratislava, Kocelova 17, Czechoslovakia).

October 14-16, 2nd International Symposium on Oncogenesis and HerpesVirus, Erlangen (Dr H. zur Hausen, Institut für Klinische Virologie, Erlangen, Germany).

October 16-18, 6th Meeting of the International Society of Paediatric Oncology, Genoa (Sixth Meeting of the International Society of Paediatric Oncology, Department of Paediatric Haematology and Oncology, Inst. Giannina Gaslini, via 5 Maggio 39, 16418 Genova-Quarto, Italy).

October 21-25, International Conference on the Properties of Hydrazine and its Potential Applications as an Energy Source, Poitiers (Centre Nat- ional d'Etudes Spatiales (CNES), Department des Affaires Universitaires, 129 rue de l'Universite, 75327 Paris Cedex 07, France).

October 27-November 1, 8th Pan American Congress of Endocrinology, Buenos Aires (Secretariat, CENI S.A., Avda. Rogue Saenz Pena 1110, Casillo de Correro 2539, Buenos Aires, Argentina).

October 28-November 2, International Conference on Plasma Theory, Kiev (Professor Sitenko, Institute of Theoretical Physics, Metrologicheskaya St, 14-Kiev, USSR).

November 4-7, 5th European Meeting of Radioisotope Producers, Athens (P. Papadimitropoulos, Director External Relations Divisions, Greek Atomic Energy Commission, Nuclear Research Center, 'Demokritos', Aghia Paraskevi Attikis, Athens, Greece).

November 4-8, 3rd International Symposium on Critical Care, Rio de Janeiro (Dr Brenildo Tavares, Director, International Symposia on Critical Care, C. Postal 14700, ZC-95, Rio de Janeiro, Guanabara, Brazil). 